\title{
Dispersion-Strengthened Gold
}

\section{IMPROVED PROPERTIES AT HIGH TEMPERATURES}

\author{
J. S. Hill \\ Engelhard Industries, Menlo Park, Edison, New Jersey \\ Where higher strength and hardness are required at elevated temper- \\ atures dispersion-strengthened gold shows considerable advantages by \\ comparison with conventional alloys. This paper describes the pro- \\ duction and testing of gold with a number of oxide dispersions which \\ are effective in enhancing its high temperature properties without \\ appreciably affecting its electrical and thermal characteristics.
}

Considerable interest has developed in recent years in dispersion-strengthened noble metals for high temperature and electrical applications (1-9). Dispersion-strengthened gold, for example, offers advantages over conventional alloys for elevated temperature applications where high strength or hardness, together with resistance to oxidation, are required without sacrifice in electrical or thermal conductivity. Dispersion-strengthened gold may thus be useful for high temperature cables and conductors, fixed and sliding electrical contacts, connectors and other electronic and aero-space applications.

In the research programme outlined here, supported by the Chamber of Mines of South Africa, samples of gold with oxide dispersions of $\mathrm{ThO}_{2}, \mathrm{Al}_{2} \mathrm{O}_{3}, \mathrm{Y}_{2} \mathrm{O}_{3}$, $\mathrm{CeO}_{2}$ and $\mathrm{TiO}_{2}$ were prepared by powder metallurgy techniques. It was found that samples containing approximately 1.0 volume per cent of oxide could readily be fabricated into wire by conventional cold working methods, and these samples were used to determine their stress-rupture, tensile, hardness, resistivity, thermal e.m.f., and abrasion resistance properties.

Thorium oxide, $\mathrm{ThO}_{2}$, was found to be particularly effective in increasing the high temperature strength of gold, while in amounts up to 1.0 volume per cent none of the oxide dispersions appreciably affected the electrical or thermoelectric properties of pure gold.

\section{Preparation of Materials}

All samples were prepared from high purity (99.99+per cent Au), -200 mesh gold powder. The same lot of gold powder was used for all experimental work in order to eliminate variations which might result from different impurity concentrations. Prior to use the gold powder was cleaned by boiling in a solution containing equal parts by volume of hydrochloric acid and distilled water. The gold powder was rinsed with hot distilled water until the wash water was free of chloride (neutral).

Admixing and thermal decomposition methods were used to prepare the gold-refractory oxide powder mixtures. In the admixing technique the refractory oxide was dispersed in distilled water to form a colloidal solution and the gold powder added to the solution. This mixture was milled to coat the surface and to distribute the oxide particles uniformly throughout the gold powder.

The decomposition technique utilised a solution of a metal salt (e.g. nitrate) or organometallic compound which was subsequently converted to the refractory oxide. The gold powder was added to this solution and the mixture heated and stirred to dryness. By heating above the thermal decomposition temperature the salt or organometallic compound was converted to the oxide.

The powder mixture was placed in a latex rubber sack and hydrostatically pressed at 30,000 psi to form a wire bar. This bar was sintered in air at $900^{\circ} \mathrm{C}$ for two hours and cooled to room temperature. Sintered bars were cold swaged with intermediate anneals and then drawn to wire. Similar pressing, sintering and working procedures were used to prepare sheet material.

\section{Test Results}

Stress Rupture

A series of stress-rupture tests was conducted on 0.050 inch diameter wire at temperatures of 800 and $900^{\circ} \mathrm{C}$. Table I summarises the data on various dispersion strengthened golds. It is apparent that of all the oxide dispersions and compositions investigated, a 0.38 volume per cent $\mathrm{ThO}_{2}$ dispersion significantly increases the high temperature strength of gold. Other oxide dispersions, even when present in much 
Table_I

Stress-Rupture Data for Dispersion-Strengthened Golds

\begin{tabular}{|c|c|c|c|c|c|c|c|c|c|c|}
\hline \multirow{3}{*}{ Composition } & \multirow{2}{*}{\multicolumn{2}{|c|}{ Per cent Oxide }} & \multicolumn{8}{|c|}{ Stress-Rupture Hours } \\
\hline & & & \multicolumn{2}{|c|}{$700^{\circ} \mathrm{C}$} & \multicolumn{3}{|c|}{$800^{\circ} \mathrm{C}$} & \multicolumn{3}{|c|}{$900^{\circ} \mathrm{C}$} \\
\hline & Weight & $\begin{array}{c}\text { Volume } \\
\text { (approx.) }\end{array}$ & $\begin{array}{l}449 \\
\text { psi }\end{array}$ & $\begin{array}{l}561 \\
\text { psi }\end{array}$ & $\begin{array}{l}561 \\
\text { psi }\end{array}$ & $\begin{array}{l}674 \\
\text { psi }\end{array}$ & $\begin{array}{l}786 \\
\text { psi }\end{array}$ & $\begin{array}{l}561 \\
\text { psi }\end{array}$ & $\begin{array}{l}786 \\
\text { psi }\end{array}$ & $\begin{array}{c}1010 \\
\text { psi }\end{array}$ \\
\hline $\mathrm{Au}$ & & & 331 & 52 & & & & & & \\
\hline $\mathrm{Au}+\mathrm{ThO}_{2}$ & 0.20 & 0.38 & & & 3075 & $2600 *$ & 2000 & 2049 & 1145 & 323 \\
\hline $\mathrm{Au}+\mathrm{Al}_{2} \mathrm{O}_{3}$ & 0.18 & 1.00 & & & & & & & 16.0 & 6.7 \\
\hline $\mathrm{Au}+\mathrm{Y}_{2} \mathrm{O}_{3}$ & 0.26 & 1.00 & & & & & & 24.0 & 2.5 & 2.5 \\
\hline $\mathrm{Au}+\mathrm{CeO}_{2}$ & 0.38 & 1.00 & & & & & & 936 & & 56 \\
\hline $\mathrm{Au}+\mathrm{TiO}_{2}$ & 0.24 & 1.00 & & & & & & 1.4 & 0.5 & \\
\hline
\end{tabular}

-Sample removed before rupture

Table II

Hardness and Tensile Properties of Dispersion-Strengthened Golds

\begin{tabular}{|c|c|c|c|c|c|c|c|c|c|c|}
\hline \multirow{3}{*}{ Composition } & & & \multicolumn{6}{|c|}{ Tensile Strength/Elongation } & \multicolumn{2}{|c|}{ DPH Hardness* } \\
\hline & \multicolumn{2}{|c|}{ Per cent Oxide } & \multicolumn{3}{|c|}{$\begin{array}{l}\text { Cold Worked } 84 \text { per } \\
\text { cent Reduction in Area }\end{array}$} & \multicolumn{3}{|c|}{ Annealed $600^{\circ} \mathrm{C}$} & \multirow{2}{*}{$\begin{array}{l}\text { Cold } \\
\text { worked } \\
84 \text { per } \\
\text { cent } \\
\text { Reduc- } \\
\text { tion in } \\
\text { Area }\end{array}$} & \multirow{2}{*}{$\begin{array}{c}\text { An- } \\
\text { nealed } \\
600^{\circ} \mathrm{C}\end{array}$} \\
\hline & Weight & $\begin{array}{c}\text { Volume } \\
\text { (approx.) }\end{array}$ & $\begin{array}{c}\text { UTS } \\
\text { psi } \\
\times 1000\end{array}$ & $\underset{\mathrm{kg} / \mathrm{mm}^{2}}{\text { UTS }}$ & $\begin{array}{c}\text { Per cent } \\
\text { Elonga- } \\
\text { tion }\end{array}$ & $\begin{array}{c}\text { UTS } \\
\text { psi } \\
\times 1000\end{array}$ & $\underset{\mathrm{kg} / \mathrm{mm}^{2}}{\text { UTS }}$ & $\begin{array}{c}\text { Per cent } \\
\text { Elonga- } \\
\text { tion }\end{array}$ & & \\
\hline $\mathrm{Au}$ & & & 35.6 & 25.0 & 1.3 & 16.0 & 11.25 & 24.3 & 69 & 49 \\
\hline $\mathrm{Au}+\mathrm{ThO}_{2}$ & 0.20 & 0.38 & 43.0 & 30.2 & 1.8 & 29.3 & 20.60 & 11.0 & 81 & 65 \\
\hline $\mathrm{Au}+\mathrm{Al}_{2} \mathrm{O}_{3}$ & 0.18 & 1.00 & 41.3 & 29.0 & 1.6 & 24.2 & 17.00 & 28.5 & 67 & 51 \\
\hline $\mathrm{Au}+\mathrm{Y}_{2} \mathrm{O}_{3}$ & 0.26 & 1.00 & 41.3 & 29.0 & 1.9 & 29.4 & 20.67 & 8.25 & 75 & 65 \\
\hline $\mathrm{Au}+\mathrm{CeO}_{2}$ & 0.38 & 1.00 & 46.2 & 32.5 & 1.5 & 31.6 & 22.2 & 16.0 & 80 & 65 \\
\hline $\mathrm{Au}+\mathrm{TiO}_{2}$ & 0.24 & 1.00 & 37.8 & 26.6 & 1.7 & 21.7 & 15.3 & 34.0 & 82 & 59 \\
\hline
\end{tabular}

-DPH Hardness-depth of penetration of a standard diamond pyramid indentor under a $\mathbf{2 5}$ gram load.

Table III

Electrical Resistance and Temperature Coefficient of Resistance (T.C.R.) of Dispersion-Strengthened Golds

\begin{tabular}{|c|c|c|c|c|c|c|c|c|c|c|}
\hline \multirow{3}{*}{ Composition } & \multicolumn{2}{|c|}{ Per cent Oxide } & \multirow{2}{*}{\multicolumn{7}{|c|}{$\begin{array}{c}\text { Electrical Resistance, Ohms Per Circular Mil Ft } \\
\text { Temperature }\end{array}$}} & \multirow{3}{*}{$\begin{array}{l}\text { T.C.R. } \Omega / \Omega /{ }^{\circ} \mathrm{C} \\
\frac{\mathrm{R}_{(100)}-\mathrm{R}_{(0)}}{\mathrm{R}_{(0)} \times 100}\end{array}$} \\
\hline & \multirow[t]{2}{*}{ Weight } & \multirow[t]{2}{*}{$\begin{array}{c}\text { Volume } \\
\text { (approx.) }\end{array}$} & & & & & & & & \\
\hline & & & $0^{\circ} \mathrm{C}$ & $25^{\circ} \mathrm{C}$ & $100^{\circ} \mathrm{C}$ & $265^{\circ} \mathrm{C} \mid$ & $514^{\circ} \mathrm{C}$ & $676^{\circ} \mathrm{C}$ & $905^{\circ} \mathrm{C}$ & \\
\hline $\mathrm{Au}$ & & & 12.45 & 13.67 & 17.21 & 26.88 & 41.19 & 50.95 & 67.42 & 0.00382 \\
\hline $\mathrm{Au}+\mathrm{ThO}_{2}$ & 0.20 & 0.38 & 12.80 & 14.09 & 17.70 & 27.73 & 42.57 & 52.78 & 70.53 & 0.00383 \\
\hline $\mathrm{Au}+\mathrm{Al}_{2} \mathrm{O}_{3}$ & 0.18 & 1.00 & 13.73 & 14.80 & 18.73 & 27.76 & 42.47 & 52.77 & 70.71 & 0.00364 \\
\hline $\mathrm{Au}+\mathrm{Y}_{2} \mathrm{O}_{3}$ & 0.26 & 1.00 & 12.86 & 14.14 & 17.81 & 27.20 & 41.78 & 51.84 & 69.58 & 0.00385 \\
\hline $\mathrm{Au}+\mathrm{TiO}_{2}$ & 0.24 & 1.00 & 12.37 & 13.57 & 17.25 & 26.40 & 40.66 & 50.53 & 68.37 & 0.00395 \\
\hline $\mathrm{Au}+\mathrm{CeO}_{2}$ & 0.38 & 1.00 & 12.79 & 14.08 & $|17.80|$ & 26.53 & 40.69 & $|50.92|$ & 68.32 & 0.00392 \\
\hline
\end{tabular}


larger quantities, do not yield a comparable strengthening effect.

\section{Hardness and Tensile Data}

Test samples were produced by drawing annealed 0.050 inch diameter wire to 0.020 inch diameter. This corresponds to an 84 per cent reduction in crosssectional area. Room temperature hardness, tensile and elongation data on cold worked and annealed samples are given in Table II. In general, an increase in hardness and tensile strength with oxide content is observed. Annealing of the cold worked material at $600^{\circ} \mathrm{C}$ results in appreciable softening, although not as much as for pure gold. High concentrations of dispersed oxide are, of course, known to inhibit recrystallisation. The data show that several oxides are equally effective in enhancing the hardness and tensile properties of gold at room temperature. Therefore, for low temperature applications which require high mechanical strength properties $\mathrm{TiO}_{2}$ or $\mathrm{CeO}_{2}$ dispersions can be used instead of $\mathrm{ThO}_{2}$.

\section{Duetility}

Samples of dispersion-strengthened gold containing up to 1.0 volume per cent of oxide have good ductility and are readily cold worked into wire or sheet. The data in Table II show that annealed tensile samples gave elongations of over 30 per cent. Even wire cold reduced 84 per cent in cross-sectional area exhibited greater than 1.0 per cent elongation in tensile tests.

Eleetrical Resistivity and Thermal E.m.f.

The electrical resistance of several oxide dispersion-strengthened golds was measured as a func- tion of temperature and compared with pure gold. As shown in Table III, the effect of 1.0 volume per cent dispersed oxide on the electrical resistance and T.C.R. (temperature coefficient of resistance) of pure gold is small.

Thermal e.m.f. measurements up to $900^{\circ} \mathrm{C}$ were also made for the dispersion-strengthened golds. E.m.f. values reported in Table IV are referenced to the $\mathrm{Pt} 27$ platinum standard. Temperatures were measured with a $\mathrm{Pt}$ vs. Pt-10Rh thermocouple traceable to the National Bureau of Standards.

E.m.f. measurements for gold wire produced from the same gold powder used for preparing the dispersion-strengthened golds are also given in Table IV. At low temperatures the thermal e.m.f. of all the dispersion-strengthened golds are very close to that of the gold wire used as a control test sample. This fact indicates that at low concentrations of dispersoid the thermal e.m.f. of pure gold is not affected by the type of insoluble oxide dispersion introduced. At higher temperatures the e.m.f. values deviate somewhat from those of the gold sample. This deviation is probably due to small differences in impurities introduced into the gold with each type of oxide dispersoid or to differences in contamination introduced during the fabrication process.

\section{Abrasion Resistance \\ Samples of dispersion-strengthened golds were produced in sheet form for wear testing. All samples were processed in the same manner to produce 0.020 inch thick sheets which were reduced 50 per cent in cross-section after annealing.}

Table IV

Thermal E.m.f. of Dispersion-Strengthened Golds versus Platinum $\left(\mathrm{Pt}_{\mathrm{t}}\right.$ 27) as a Function of Temperature

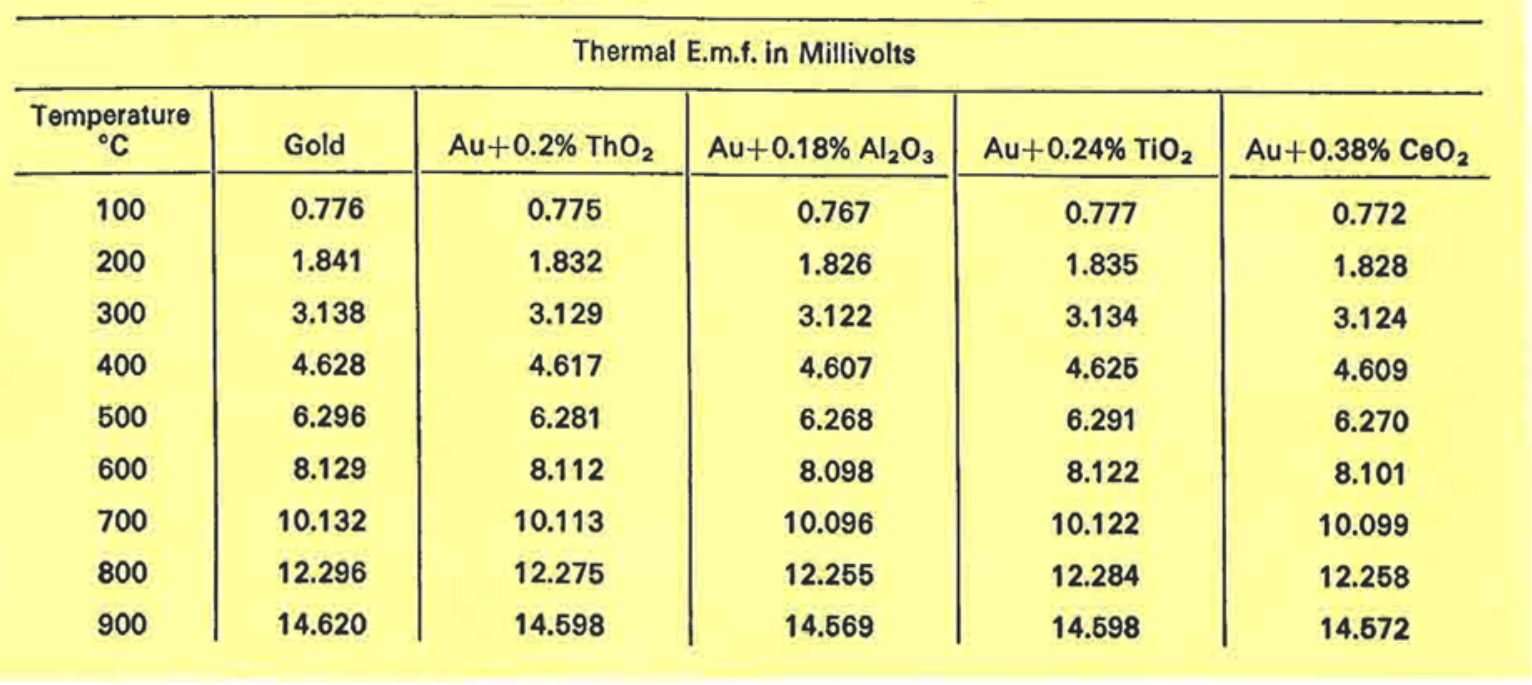




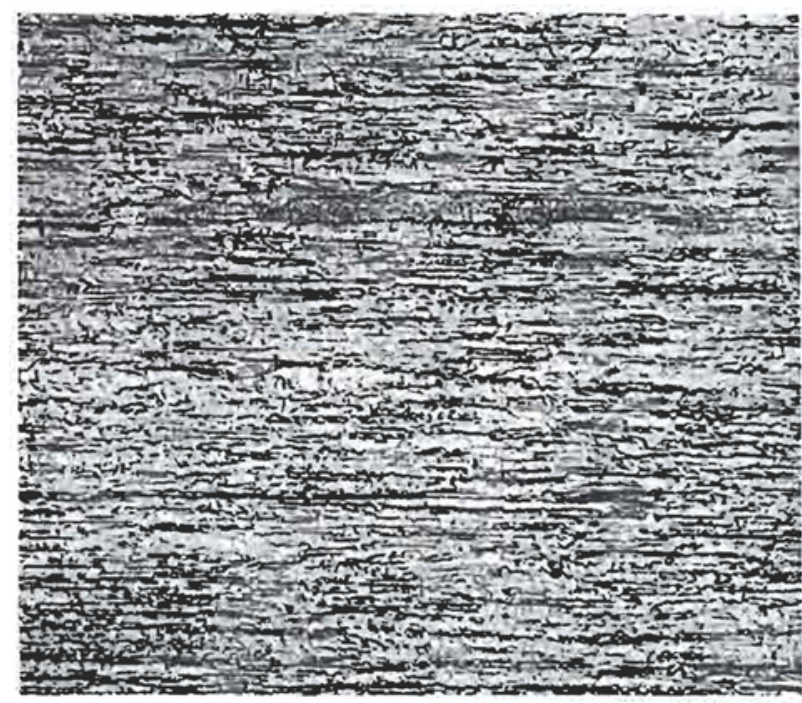

Fig. 1 Longitudinal section of dispersion-strengthened gold wire containing 0.2 weight per cent $\mathrm{ThO}_{2}$ after 84 per cent reduction in area, the microstructure being typical of the materials produced. The uniform distribution of the dispersoid is clearly seen

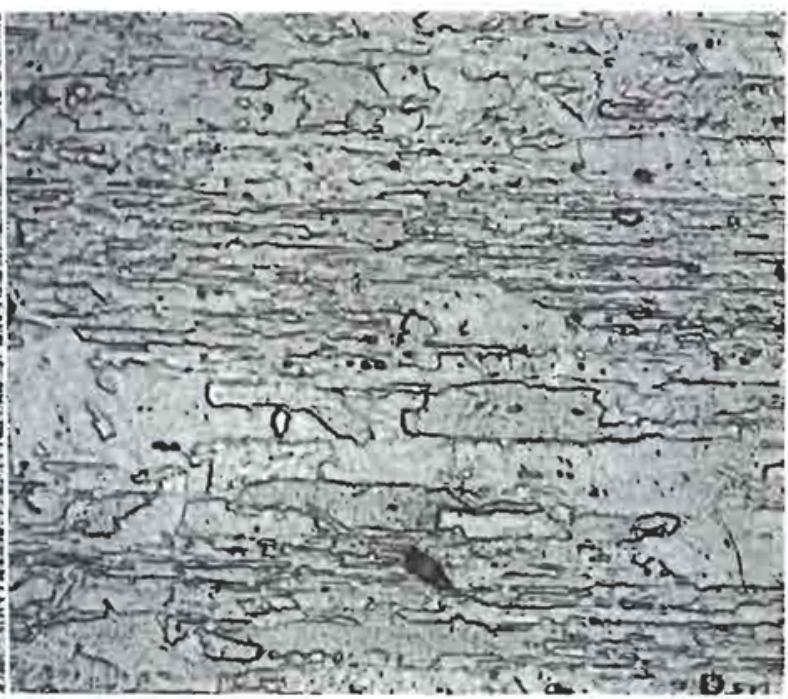

Fig. 2 Longitudinal section of 0.050 inch diameter dis. persion-strengthened gold wire also containing 0.2 weight per cent Tho $\mathrm{T}_{2}$ after stress-rupture testing at $900^{\circ} \mathrm{C}$ for 1145 hours with a 700 gram load. Photographed approximately one inch from break
Resistance to wear was measured using a standard abrasion tester manufactured by Taber Instruments. A 1000 gram load was applied to the abrasive wheel for 1000 cycles and the wear was determined from the average of three tests. Test results are given in Table V.

Approximately twice as much weight loss was observed for the pure gold control sample in the standard wear test as was obtained for any of the dispersion-strengthened golds. These results show that oxide dispersions in gold significantly increase its resistance to abrasive wear.

\section{Discussion of Results}

Powder metallurgy techniques used in this investigation produced dispersion-strengthened golds with a uniform distribution of oxide dispersoid. Figure 1 is a photomicrograph of $\mathrm{Au}+0.2$ weight per cent $\mathrm{ThO}_{2}$ but the microstructure of this composition is typical of all the materials produced.

The high temperature stability imparted to the elongated grain structure by the oxide dispersion is readily apparent from an examination of Figure 2. This shows that elongated grains in a stress-rupture test sample persist even after exposure to $900^{\circ} \mathrm{C}$ for 1145 hours. The microstructural evidence described above, supported by the hardness and tensile data, confirms that oxide dispersions such as $\mathrm{ThO}_{2}$ are extremely effective in retarding recrystallisation and grain growth in gold.

All the dispersion-strengthened golds exhibited superior mechanical properties compared with pure gold, particularly at elevated temperatures. For the pressing, sintering and working procedures used in this investigation, optimum strength properties were observed in golds containing approximately 1.0 volume per cent of dispersoid. High dispersion content decreased the ductility of gold, making the materials difficult to work and causing cracking during working.

The electrical resistivity, temperature coefficient of resistance and thermal e.m.f. of dispersionstrengthened gold are properties which are nearly independent of the type of insoluble oxide dispersion, at least for the low oxide concentrations $(\sim 1.0$ volume per cent) investigated. The electrical resistivity was greater than that predicted by a simple averaging of the contributions, based on the

Table V

Wear Test Data on Dispersion-Strengthened Golds

\begin{tabular}{|c|c|c|c|}
\hline \multirow{2}{*}{ Composition } & \multicolumn{2}{|c|}{ Per cent Oxide } & \multirow{2}{*}{$\begin{array}{c}\text { Milligrams } \\
\text { wear per } \\
1000 \\
\text { cycles }\end{array}$} \\
\hline & Weight & $\begin{array}{l}\text { Volume } \\
\text { (approx.) }\end{array}$ & \\
\hline $\mathrm{Au}$ & - & - & 14 \\
\hline $\mathrm{Au}+\mathrm{Al}_{2} \mathrm{O}_{3}$ & 0.18 & 1.0 & 6 \\
\hline $\mathrm{Au}+\mathrm{Y}_{2} \mathrm{O}_{3}$ & 0.26 & 1.0 & 8 \\
\hline $\mathrm{Au}+\mathrm{ThO}_{2}$ & 0.20 & 0.38 & 8 \\
\hline $\mathrm{Au}+\mathrm{C}_{\ominus} \mathrm{O}_{2}$ & 0.38 & 1.0 & 7 \\
\hline $\mathrm{Au}+\mathrm{TiO}_{2}$ & 0.24 & 1.0 & 8 \\
\hline
\end{tabular}


volume fraction of each phase present in the mixture. This deviation is attributed to impurities and imperfections introduced during the processing steps rather than to the nature of the dispersed phase per se. The slight increase in T.C.R. observed in most dispersion-strengthened golds (see Table III) can also be explained by the presence of impurities. It is also well known that the thermal e.m.f. of gold is extremely sensitive to impurities, particularly at elevated temperatures. Therefore the small e.m.f. differences observed for dispersion-strengthened golds compared with the control sample of pure gold may not be significant.

\section{Conclusion}

This investigation shows that the addition of a stable oxide dispersion in gold improves very dramatically the hardness, strength and wear resistance of the composite as compared with pure gold without decreasing appreciably some of the important intrinsic properties of gold such as oxidation resistance and electrical (and thus the thermal) conductivity. We have shown that superior mechanical properties can be obtained when 1.0 volume per cent of an oxide dispersoid is added to gold and that conventional cold working techniques can be used.

The properties of dispersion-strengthened gold suggest its use for applications requiring good mechanical properties (tensile and/or hardness) at low or elevated temperatures $\left(500\right.$ to $600^{\circ} \mathrm{C}$ ), combined with low electrical resistance and oxidation resistance at high temperature. Other possible electrical and electronic applications would include its use in connectors, high temperature conductors, electrodes, thermocouples and bonding wire. Many applications within the chemical industry may also develop for dispersion-strengthened gold laboratory apparatus.

In respect to electrical contact applications, we have determined that oxide-strengthened gold affords a greater resistance to arc erosion with lower tendency to sticking and welding.

Furthermore, compared with pure gold, it has an equivalent thermal and electrical conductivity and a reasonably low contact resistance. The outstanding electrical contact properties of dispersion-strengthened gold will be described in detail in a later paper.

\section{References}

1 N. Fuschillo and M. L. Gimpl, f. Mater. Sci., 1970, 5, (12), 1078

2 M. L. Gimpl and N. Fuschillo, f. Metals, 1971, 23, (6), 39

3 M. Poniatowski and M. Clasing, Gold Bull., 1972, 5, (2), 34

4 U.S. Patent 2,947,114 Engelhard Industries, 1960

5 U.S. Patent 2,984,894 Engelhard Industries, 1961

6 U.S. Patent 3,049,577 Engelhard Industries, 1962

7 U.S. Patent 3,201,236 Engelhard Industries, 1965

8 U.S. Patent 3,606,766 Engelhard Industries, 1971

9 C. Larson, Gold Bull., 1975, 8, (4), 127

\section{The Surface Self-Diffusion of Gold}

\section{EFFECT OF ADSORBED TRACES OF BISMUTH}

For some years G. E. Rhead, of the University of Paris, has been active in the study of the remarkable effects of adsorbed impurities on surface self-diffusion of metals. He has found, for instance, that traces of chlorine, bromine, and iodine can promote very high rates of self-diffusion on copper surfaces over the temperature range 380 to $1050^{\circ} \mathrm{C}$. On silver surfaces, traces of sulphur have a similar accelerating effect.

It is, however, on gold surfaces that some of the most dramatic changes are observed, and in a recent note from his laboratory (Comptes Rendus [C], 1975, 280, 489) Jean-Paul Biberian reports that the presence of a monolayer of adsorbed bismuth increases the coefficient of surface self-diffusion at 600 to $950^{\circ} \mathrm{C}$ by a factor of as much as 10,000 .

In the experiments described, an electrolytically polished sample of pure gold, 99.999 fine, was maintained for 1 to 10 hours at a steady temperature in the region studied. A slow stream of argon at atmospheric pressure was used to transport bismuth vapour (derived by passing it over bismuth at a lower temperature than that of the gold) over the gold.

The effect of this treatment was to develop deep grooves, flanked with mounds banked-up above the level of the gold surface along the grain boundaries. By measuring the depth and width of the grooves and the height of the mounds the coefficient of surface self-diffusion could be calculated.

There are two main explanations for this effect-that a "two-dimensional" compound having a low melting point is formed covering the surface with a "molten" layer, one atom thick, in which individual atoms move freely, or that some substrate atoms climb on top of the adsorbed layer and can then "jump" or "skate" or otherwise migrate by distances of the order of 100 atoms. Rhead considers that there is still insufficient evidence to decide which is correct.

Whatever may be the explanation, these observations may be of considerable importance in connection with powder metallurgy. The nature of the forces responsible for eliminating voids during heat treatment has long been a matter of debate but undoubtedly surface diffusion plays an important role in the mechanism of the sintering process.

Thus adsorbed layers derived from sintering atmospheres may have a significant effect, hitherto unappreciated, on the consolidation of metallic powder compacts.
J. C. C. 